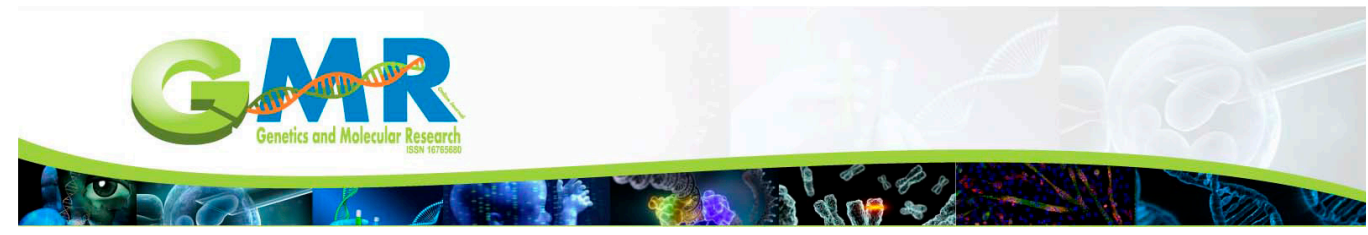

$\underline{\text { Retraction }}$

\title{
RETRACTION of articles with plagiarism in common with other publications
}

\author{
Genet. Mol. Res. 15 (3): gmr.1503007 \\ Published September 30, 2016 \\ DOI http://dx.doi.org/10.4238/gmr.1503007
}

The GMR editorial staff was alerted about some manuscripts that were found to be substantially equal. The Publisher and Editor decided to retract these articles in accordance with the recommendations of the Committee on Publication Ethics (COPE). After a thorough investigation, we have strong reason to believe that the peer review process was failure and, after review and contacting the authors, the editors of Genetics and Molecular Research decided to retract these articles. The authors and their institutions were advised of this serious breach of ethics.

The articles containing plagiarism in common with other publications are:

Peng ZA, Lu RB, Xiao DM and Xiao ZM (2016). Increased expression of the IncRNA BANCR and its prognostic significance in human osteosarcoma. Genet. Mol. Res. 15 (1): gmr15017480 - DOI http://dx.doi.org/10.4238/gmr.15017480

This study describes the potential association of lncRNA BANCR in human osteosarcoma, which can be used as a potential biomarker for osteosarcoma prognosis, and can act as a target for therapeutic treatment.

The manuscript contains large sections of duplicated text from already available resources in all the major sections. Even the figure 3 and its subfigures are duplicated and modified from the study "Increased expression of LncRNA BANCR and its prognostic significance in human hepatocellular carcinoma" (http://link.springer.com/article/10.1186/s12957-015-0757-5).

Several other major studies, from where the texts have been copied substantially, were found and two of them can be accessed at: [www.dovepress.com/mir-32-functions-asa-tumor-suppressor-and-directly-targets-sox9-in-hu-peer-reviewed-fulltext-article-OTT\#F1] and [www.dovepress.com/overexpression-of-long-noncoding-rna-hottip-promotes-tumorinvasion-an-peer-reviewed-fulltext-article-OTT].

\section{Link to original paper}

Genetics and Molecular Research 15 (3): gmr.1503007 
Man HB, Bi WP and Man HH (2016). Decreased microRNA-198 expression and its prognostic significance in human glioma. Genet. Mol. Res. 15 (2): gmr.15027656 DOI http://dx.doi.org/10.4238/gmr.15027656

This study describes the potential association of microRNA-198 with human glioma, one of the most common tumors of the central nervous system. This has potential implications in biomarker development for glioma prognosis, and can act as a target for therapeutic treatment.

However, the manuscript contains portions copied from already published studies in all the major sections including the Introduction, Material and Methods, Results, and Discussion. The Abstract is not plagiarized.

Figures 1 and 3, along with their legends, are duplicated and modified from the study "MicroRNA-32 functions as a tumor suppressor and directly targets EZH2 in uveal melanoma" (http://www.ncbi.nlm.nih.gov/pubmed/27323022).

Several other major studies, from where the texts have been copied substantially, can be accessed at: [http://www.funpecrp.com.br/gmr/year2016/vol15-2/pdf/gmr7730.pdf], [www.ncbi.nlm.nih.gov/pmc/articles/PMC4744396/], and [https://wjso.biomedcentral.com/ articles/10.1186/s12957-015-0757-5].

\section{Link to original paper}

Tang T, Zhang GC, Li CF, Liu YF, et al. (2016). Decreased miR-452 expression in human colorectal cancer and its tumor suppressive function. Genet. Mol. Res. 15 (2): gmr.15027730 DOI http://dx.doi.org/10.4238/gmr.15027730

This study describes the potential tumor suppressor function of miRNA-452 in colorectal cancer. The manuscript contains sections of duplicated text from already available resources. All the major sections, except the abstract, have substantial amount of plagiarism. The figures 1, 2 and 3 along with their legends are directly copied and modified from the study "Decreased expression of miR-874 and its tumor suppressive function in human colorectal cancer" (www.funpecrp.com.br/gmr/year2016/vol15-2/pdf/gmr8077.pdf).

Several other major studies, from where the texts in all other sections have been copied substantially, were found and two of them can be accessed at [www.funpecrp.com.br/gmr/ year2016/vol15-2/pdf/gmr7656.pdf] and [www.ncbi.nlm.nih.gov/pmc/articles/PMC4709863/].

\section{Link to original paper}

Ma YB, Song DW, Nie RH and Mu GY (2016). MicroRNA-32 functions as a tumor suppressor and directly targets EZH2 in uveal melanoma. Genet. Mol. Res. 15 (2): gmr.15027935 - DOI http://dx.doi.org/10.4238/gmr.15027935

This research describes the potential tumor suppressor function of miRNA-32 in uveal melanoma, which is one of the most common malignancies of the eye. The study is conducted well, with a rigorous review of literature, robust methodology, well-defined results, and a narrative discussion, but, unfortunately, there are serious issues of plagiarism.

Genetics and Molecular Research 15 (3): gmr.1503007 
The manuscript contains sections copied from already published studies, except the Abstract. Even the figures, especially Figures 1B, 2A and 2B, and 3B and 3C, along with their legends, are duplicated and modified from the study "MiR-32 functions as a tumor suppressor and directly targets EZH2 in human oral squamous cell carcinoma" (europepmc.org/articles/ PMC4266205).

Several other major studies, from where the texts have been copied substantially, were found and some of them can be accessed at [europepmc.org/articles/PMC4166217], [www. funpecrp.com.br/gmr/year2016/vol15-2/pdf/gmr7656.pdf], [www.funpecrp.com.br/gmr/ year2016/vol15-2/pdf/gmr7730.pdf], and [www.ncbi.nlm.nih.gov/pubmed/26048406].

\section{Link to original paper}

Wang XJ, Xia M and Bi WP (2016). Decreased expression of miR-874 and its tumor suppressive function in human colorectal cancer. Genet. Mol. Res. 15 (2): gmr.15028077 DOI http://dx.doi.org/10.4238/gmr.15028077

Wang et al. explore the role of a specific microRNA, miR-874, in colorectal cancer. The authors' analysis of miR-874 levels in CRC cell lines and in human cancer specimens demonstrates that miR-874 expression is significantly downregulated in colorectal cancer and is associated with a higher propensity for tumor progression and metastasis.

Unfortunately, the manuscript has substantial plagiarism with numerous other publications, in particular: "Decreased miR-154 expression and its clinical significance in human colorectal cancer" (www.ncbi.nlm.nih.gov/pubmed/26048406). This duplication extends to the figures, especially Figure 3.

\section{Link to original paper}

Zhuo HC, Song YF, Ye J, Lai GX, et al. (2016). MicroRNA-154 functions as a tumor suppressor and directly targets HMGA2 in human non-small cell lung cancer. Genet. Mol. Res. 15 (2): gmr.15028173 - DOI http://dx.doi.org/10.4238/gmr.15028173

This paper is plagiarized from several sources and the data set is exactly duplicated from several publications. This means that the biology described for miR-154 is likely not true.

It is alarming that it seems that this exact publication and data set have been published numerous times identifying different miRNAs playing a role in cancer biology. These publications include: "miR-32 functions as a tumor suppressor and directly targets SOX9 in human non-small cell lung cancer" by Zhu et al. - OncoTargets and Therapy (2015), "miR215 functions as a tumor suppressor and directly targets ZEB2 in human non-small cell lung cancer" by Hou et al. - Oncology Letters (2015), "MiR-32 functions as a tumor suppressor and directly targets EZH2 in human oral squamous cell carcinoma" by Zhang et al. - Medical Science Monitor (2014), "MiR-206 functions as a tumor suppressor and directly targets K-Ras in human oral squamous cell carcinoma" by Lin et al. - OncoTargets and Therapy (2014), and "Decreased microRNA-224 and its clinical significance in non-small cell lung cancer patients" by Zhu et al. - Diagnostic Pathology (2014). 